Jurnal Keperawatan Padjadjaran

ISSN 2338-5324 (print)

ISSN 2442-7276 (online)

Online di http://jkp.fkep.unpad.ac.id

DOI : $10.24198 / \mathrm{jkp}$

\title{
Child Health Problems in Agricultural Setting
}

\author{
Lantin Sulistyorini*, Peni Perdani J, Ira Rahmawati, Eka Afdi S \\ Faculty of Nursing, Universitas Jember, Jember, Indonesia \\ Corresponding Email: lantin_s.psik@unej.ac.id
}

Submitted: 15-07-2020 Accepted: 24-09-2020 Published: 30-12-2020

\begin{abstract}
Besuki Residency well known at agricultural field. Child and infant mortality in this area is high. Child health problems of agricultural-oriented at Besuki Residency no one has research yet. This research uses quantitative methods that are retrospectives that include child health problems since 2017 until 2018. Quantitative method is used to collect data on patient characteristics (gender, disease, nursing problems, and age criteria) and illness to the children's disease based on agricultural that arise due to activities or agricultural climate. The sample included 807 children at seven hospital scattered in several residency areas using quota sampling technic. Data analysis uses confirmatory factor analyze (CFA), with parameter data estimation uses analysis of moment structures. The result of $\mathrm{p}$-values for health problems to gender $=0.033(\mathrm{p}<0.05)$, health problems to disease $=0.008(\mathrm{p}<0.05)$, health problems to nursing problems $=0.000(\mathrm{p}<0.05)$, health problems to age criteria $=$ $0.000(p<0.05)$. Fit model value indicates that the model is perfect fit. Child health problems, especially such as pneumonia, diarrhea, and malaria in the agricultural area with an agricultural perspective in the Besuki Residency can affect gender, disease, nursing problems, and age criteria. So that these health problems require specific health interventions or programs according to the characteristics of gender, disease, nursing problems, and age criteria. The nurse should have a mapping of nursing problems and special agriculture-oriented interventions.
\end{abstract}

Keywords: Age criteria, agricultural, child, disease, gender, health problems, nursing problems. 


\section{Introduction}

Children are unique individuals whose most periods of life are growing and developing. One of indicator in determining the health status of children is the Infant Mortality Rate (IMR) and Toddler Mortality Rate (TMR). In Indonesia from 1990-2005 there was a lot of progress in reducing IMR and TMR but in the last decade there has been a slowdown, especially has to be juxtaposed with ASEAN, Indonesia is still lagging behind (UNICEF, 2012).

Health problems such as pneumonia, diarrhoea and malaria are still the main causes of child mortality globally. Many children die less than five years of age due to preventable diseases. Whereas in the child's life cycle, the first month of a child's life or the neonatal period is the most dangerous period for children, where most of the causes can be prevented (UNICEF, 2013). Therefor, a preventive effort is needed in mitigating it. One effort to reduce child morbidity and mortality is to perform health maintenance where the initial action that can be taken is to map children's health problems of agricultural-oriented.

Each year, pneumonia causes about 700,000 to 900,000 child deaths worldwide (Troeger et al., 2017). In 2016, the incidence of pneumonia was $13-16 \%$ of all deaths in children under 5 years (Troeger et al., 2017). In 2015, the worldwide death burden from pneumonia in several countries: Afghanistan, Angola, Bangladesh, Chad, China, Democratic Republic of the Congo, Ethiopia, India, Indonesia, Niger, Nigeria, Pakistan, Somalia, Sudan and Tanzania reached $70 \%$ of all pneumonia deaths worldwide (WHO, 2018). In 2011, as many as 1-3 million cases of pneumonia were fatal, and $81 \%$ of these deaths occurred within the first 24 months of life. Child mortality from pneumonia decreases rapidly with age, from about $67 \%$ of all deaths at 6 months to $14 \%$ at 18 months, and reaching $6 \%$ between the ages of 30 and 54 months. The incidence decreased gradually with increasing age, namely around $39 \%$ at 6 months, $22 \%$ at 18 months, $19 \%$ at 30 months, $13 \%$ at 42 months, and $7 \%$ at 54 months (Walker et al., 2013).

The implementation of integrated management of under-five sick children (IMCI) has been shown to reduce pediatric morbidity and improve the quality of health services provided to children (Ahmed et al., 2010). The results illustrate that there is suboptimal adherence to the guidelines in various settings (Baiden et al., 2011; Irimu et al., 2012). It is in the context of pneumonia surveillance that the management of pneumonia in children less than 5 years of age in Mozambique, a low-income country with a high mortality rate for children less than 5 years of age and a high burden of disease and death from pneumonia and malaria (Acacioa et al., 2015).

Diarrhoea is a major killer of children under five years of age (Walker et al., 2013; Santosham et al., 2010; Pahwa et al., 2010). According to UNICEF (2016a), in 2015 as much as $9 \%$ of all deaths were in children under five years of age. This means that more than 1400 children die every day, or about 530,000 children every year from diarrhoea. In 2013 in India diarrhoea caused more than 130,000 child deaths (UNICEF, 2016b). About a quarter of all diarrheal deaths worldwide are in children under the age of five (Liu et al., 2015). Most of the deaths from diarrhoea result from loss of fluids and excess electrolytes that lead to dehydration. Death due to diarrhoea can be avoided with simple medications such as oral rehydration solutions and other fluids available at home, continuous feeding during episodes of diarrhoea and breastfeeding. This treatment is recognized in reducing child mortality and morbidity (Dutta et al., 2016).

So we need a preventive effort to overcome it. One of the efforts to reduce child morbidity and mortality is by carrying out health care where the initial action that can be taken is mapping children's health problems.

\section{Method}

This research uses quantitative methods that are retrospectives that include child health problems since 2017 until 2018. Quantitative method is used to collect data on patient characteristics and illness to the children's disease based on agricultural that arise due to activities or agricultural climate. 
The population of the research was inclusion criteria includes pediatric patients who have been treated with major nursing problems from several children diseases based on agricultural in seven hospital in all the Besuki Residency include there are three hospital agricultural, and the others are local hospital that near from agricultural region. The sample includes secondary data derived from medic record data $(\mathrm{n}=807)$. The sampling technique uses quota sampling.

Data analysis uses confirmatory factor analyze (CFA), with parameter data estimation uses analysis of moment structures (AMOS versi 21) (Byme, 2013). CFA is an approach used to analyze measurement models. The analysis is intended to reveal how well the measurement indicators measure a latent concept (construct), so as to get a good model.
The CFA test aims to find out how well the measurement indicators measure a latent concept (construct) such as gender, disease, nursing problems, and age criteria and to find out the fit value of the model in Chisquared, p-value, root mean square error of approximation (RMSEA), and comparative fit index (CFI).

Take from the research ethic committee faculty of dentistry Universitas Jember with number: 503/UN25.8/KEPK/DL/2019 and take informed consent from respondent.

The research instrument uses a medical record to determine health problems such as gender, disease, nursing problems, and age criteria. Data collection techniques include filling in the format of disease number data (table 1).

Table 1 Data of Children Disease Based on Agricultural

\begin{tabular}{ll}
\hline \multicolumn{1}{c}{ Item } & \multicolumn{1}{c}{ Disease } \\
\hline Components of children's disease based on agricultural \\
$\begin{array}{l}\text { Respiratory disease } \\
\text { Gastrointestinal disease }\end{array}$ \\
Skin disease & $\begin{array}{l}\text { Diarrhoea, profus vomiting } \\
\text { Dermatitis atopic, scabies, eczema ex herpes simplex / Atopic } \\
\text { dermatitis, scabies, eczema ex herpes simplex }\end{array}$ \\
Toxicology & $\begin{array}{l}\text { Premature babies, babies with congenital disorders, cancer (brain } \\
\text { cancer, acute lymphocytic leukemia, and non-Hodgkin lymphoma), }\end{array}$ \\
zropical Disease & Thyposis (filariasis) \\
Growth and development & \\
Child Characteristics & \\
Age & \\
Gender & \\
Adress &
\end{tabular}

Table 1 shows that the data on diseases suffered by children in the agricultural area. Most of the diseases that affect children include respiratory diseases, gastrointestinal diseases, skin diseases, poisoning and tropical diseases.

\section{Results}

Health problems (X1) are measured through 4 aspects of indicators, namely gender (X1.1), disease (X1.2), nursing problems (X1.3), and age criteria (X1.4). Descriptive analysis results can be seen in table 2 .
Table 2 shows that the sex is mostly male, the disease caused is mostly ARI, the nursing problem that often arises is mostly hypertension, the age criterion is mostly toddlers.

The variable and each indicator are shown in Figure 1.

In figure 2 shows that the estimated significance of the parameters produced by the character of health problems (X1) to gender $(\mathrm{X} 1.1)=0.089$.

Estimation of health problems (X1) to disease $(\mathrm{X} 1.2)=0.472$. Estimation of health problems (X1) to nursing problems (X1.3) 
Lantin Sulistyorini: Child Health Problems in Agricultural Setting

Table 2 Characteristics of Respondents by Gender, Disease, Nursing Problems, and Children's Age Criteria

\begin{tabular}{|c|c|c|}
\hline Characteristic & f & $\%$ \\
\hline \multicolumn{3}{|l|}{ Gender } \\
\hline Man & 438 & 54.3 \\
\hline Woman & 369 & 45.7 \\
\hline \multicolumn{3}{|l|}{ Disease } \\
\hline UTI & 47 & 5.8 \\
\hline ARI & 363 & 45.0 \\
\hline Diarrhea & 136 & 16.9 \\
\hline Convulsions & 116 & 14.4 \\
\hline Typhoid & 16 & 2.0 \\
\hline DHF & 36 & 4.5 \\
\hline Blood disorders & 35 & 4.3 \\
\hline Other infections & 37 & 4.6 \\
\hline Congenital disorders & 8 & 1.0 \\
\hline $\mathrm{TBC}$ & 7 & 0.9 \\
\hline Another malignancy case & 2 & 0.2 \\
\hline Morbilli & 4 & 0.5 \\
\hline \multicolumn{3}{|l|}{ Nursing problem } \\
\hline Hypertension & 378 & 46.8 \\
\hline Lack of Fluid Volume & 61 & 7.6 \\
\hline The Ineffectiveness of Breathing Pattern & 56 & 6.9 \\
\hline The Ineffectiveness of Clearance air ways & 134 & 16.6 \\
\hline Ineffective Thermoregulation & 10 & 1.2 \\
\hline Constipation & 4 & 0.5 \\
\hline Diarrhea & 17 & 2.1 \\
\hline Comfort Disorders & 24 & 3.0 \\
\hline Risk of injury & 9 & 1.1 \\
\hline Activity intolerance & 2 & 0.2 \\
\hline Acute Pain & 64 & 7.9 \\
\hline Ineffectiveness of Tissue Perfusion & 25 & 3.1 \\
\hline Skin Integrity Damage & 1 & 0.1 \\
\hline Aspiration Risk & 1 & 0.1 \\
\hline Potential Complications of Anemia & 1 & 0.1 \\
\hline Nutrition Needs Less Than Body Needs & 16 & 2.0 \\
\hline Excess fluid & 4 & 0.5 \\
\hline \multicolumn{3}{|l|}{ Age Fluid } \\
\hline Neonatus & 13 & 1.6 \\
\hline Infant & 143 & 17.7 \\
\hline Toddler & 280 & 34.7 \\
\hline Preschool & 161 & 20.0 \\
\hline School & 152 & 18.8 \\
\hline Teenaer & 58 & 7.2 \\
\hline
\end{tabular}

Volume 8 Issue 3 December 2020 


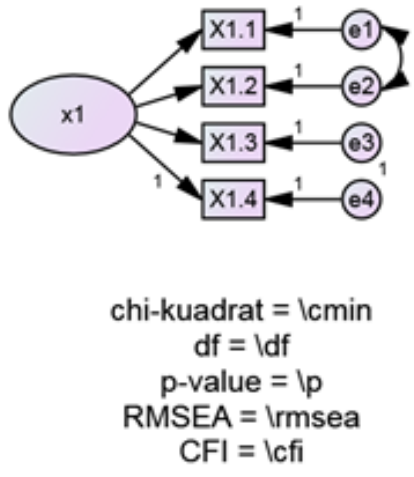

Figure 1 Hypothesis Model: Confirmatory Factor Analyze: Children Health Problems based on agricultural in Besuki Residency

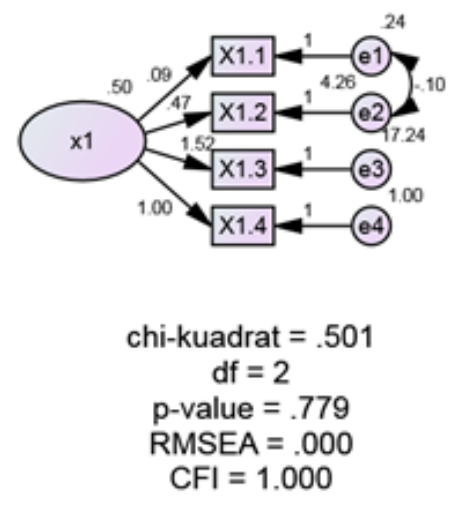

Figure 2 Confirmatory Factor Analyze: Children Health Problems based on Agrocultural in Besuki Residency

$=1.525$. Estimated health problems $(\mathrm{X} 1)$ to age criteria $(\mathrm{X} 1.4)=1.000$.

\section{Estimation of Parameter Significance}

Table 3 shows that the result of $\mathrm{p}$-values for health problems (X1) to gender (X1.1) amounted to 0.033 this values $<0.05$, then gender (X1.1) is expressed a significant as measure construct of health problems (X1).
P-value generated for health problems (X1) to disease $(\mathrm{X} 1.2)$ amounted to 0.008 this value $<0.05$, then disease (X1.2) is expressed significant as measure construct of health problems (X1). P-value generated for health problems (X1) to nursing problems (X1.3) amounted to 0.000 this value $<0.05$, then nursing problems (X1.3) are expressed significant as measure construct of health

Table 3 Estimation of the Significance of Gender Parameter, Disease, Nursing Problem, and Age Criteria

\begin{tabular}{lcc}
\hline \multicolumn{1}{c}{ Variables } & Estimate & p-value \\
\hline Health Problems (X1) ----> Gender (X1.1) & 0.089 & 0.033 \\
Health Problems (X1) ----> Disease (X1.2) & 0.472 & 0.008 \\
Health Problems (X1) ----> Nursing Problems (X1.3) & 1.525 & 0.000 \\
Health Problems (X1) ----> Age Criteria (X1.4) & 1.000 & 0.000 \\
\hline
\end{tabular}


Fit Model Value

Table 4 Fit Model Value on Chi-square, p-Value, Root Mean Square Error of Approximation (RMSEA), and Comparative Fit Index (CFI)

\begin{tabular}{|c|c|}
\hline Model & Value \\
\hline \multicolumn{2}{|l|}{ Default Model: } \\
\hline Chi-square & 0.501 \\
\hline P-Value & 0.779 \\
\hline RMSEA & 0.000 \\
\hline CFI & 1.000 \\
\hline
\end{tabular}

problems (X1). P-value generated for health problems (X1) to age criteria (X1.4) amounted to 0.000 this value $<0.05$, then age criteria (X1.4) are stated a significant as measure construct of health problems (X1).

\section{Fit Model Value}

Table 4 shows that the Chi-square fit index value generated is 0.501 , because it approaches 0 the more fit, it means that the model is fit. The index value of fit $p$-value generated is 0.779 , because $\alpha=0.05$, then fit, it means that the model is fit. RMSEA index fit value generated is 0.000 , because $\leq 0.05$, then fit, it indicates that the model is fit. CFI fit index value generated is 1,000 , because $>$ 0.90 then fit, it indicates that the model is perfect fit.

\section{Discussion}

\section{Health Problems Effect to Gender}

The results of this study show that children hospitalized during 2017-2018 were male by $54.3 \%$, greater than girls $(45.7 \%)$. This result is the same as the results of a study in Ethiopia which showed higher morbidity in boys $(12.2 \%)$ than girls $(11.1 \%)$. However, different results were shown in a study in Northern Ethiopia which showed the prevalence of morbidity between boys and girls was the same, namely $50 \%$. Gender have significant results as a measure of the construct of health problems. This study showed that ARI had the highest rate from the others diseases. The results showed that gender influences ARI rate because hormones 17 gamma-estradiol. It can help stabilization of body and increase immunity if there are inflammation mediator agent such as TNF, IL-2, IL-4, IL-6, IL-8 and IFN-gamma. The mediator usable to fight infection. Male Child with his testosterone hormones delay production of the agent (Iskandar et al., 2015).

\section{Health Problems Effect to Disease}

Throughout 2017-2018 the number of children in the Besuki Agriculture area who had to be hospitalized due to ARI was $45 \%$. This result is higher than the number of children with ARI in India (41.6\%) (Savitha \& Gopalakrishnan, 2018), Northern Ethiopia (27.3\%) (Dagne et al., 2020).

ARI often attacks children under five years of age who experience an average of three to six episodes of events per year. More than 12 million children reported experiencing ARI hospitalization globally in 2010. ARI is classified into upper respiratory tract infection (URI) and lower respiratory tract infection (LRI). URI attacks the upper airway covering the nose to the vocal cords on the larynx, including the paranasal sinuses and middle ear. Whereas LRI attacks the lower airways starting from the trachea, bronchi to bronchioles and alveoli (Nair et al., 2013).

Many large-scale changes in environmental and demographic conditions increase the risk of infectious disease. This risk is increasing due to increasing antibiotic resistance, the use and abuse of antibiotics can increase the process of emergence and spread of pathogenic bacteria in humans (WHO, 2013). In children who experience problems with nutrition due to lack of nutrients eaten can also increase the risk of experiencing diarrhea and respiratory disease (WHO, 2013). Factors such as mothers with complications of 
childbirth, children who are not breastfed can put them at risk of malnutrition (Rahayuwati et al., 2019).

\section{Health Problems Effect to Nursing problems}

Nursing Problems have significant results as a measure of the construct of health problems. The results showed hyperthermia is a nursing problem that most often occurs in children with all diseases, especially ARI. Hyperthermia is an increase of core body temperature that occurs due to infection. Pro inflammatory cytokines interleukin 1 (IL-1), interleukin 6 (IL-6) and tumor necrosis factor alpha (TNF) act as endogenous pyrogens that stimulate a child who has a fever if infected. Every increase of body temperature of one degree Celsius will increase carbohydrate metabolism $10-15 \%$ so that an increase of temperature effects to the increase in glucose and oxygen needs..

\section{Health Problems Effect to age criteria}

The age of the child has significant results as a measure of the construct of children's health problems in the Besuki Residency. The age of children under 5 years most often experience health problems both ARI or other diseases due to the influence of the immune system. The immune system is the body's defence against organisms which is the result of collaboration from a series of cells, tissues, proteins and organs. As a child ages, the immune system also develops (Simon et al., 2015).

This is the reason why children under five years are vulnerable to infection or illness. This is in line with the results of research that where an increase in the percentage of CD4 + and CD8 + memory cells as children ages. That's why, if a child under five years is in direct contact with someone who has symptoms of respiratory disease can significantly increase the risk of children experiencing ARI, so child under five years need to be kept away from people who have coughs or other symptoms of the disease to prevent child under five years from becoming infected with the disease. Providing supplementary food and health promotion of nutritional status can improve health (Fitriani, Setya, \& Nurdiana, 2020).

\section{Conclusion}

Child health problems, especially such as pneumonia, diarrhea, and malaria in the agricultural area with an agricultural perspective in the Besuki Residency can affect gender, disease, nursing problems, and age criteria. So that these health problems require specific health interventions or programs according to the characteristics of gender, disease, nursing problems, and age criteria. The nurse should have a mapping of nursing problems and special agricultureoriented interventions.

\section{References}

Acacioa, B., Jennifer, R., Veranic, Lanaspaa, M., Tarayn, A., Fairliec, Nhampossaa, T., Rupereza, M., Aidea, P., Brian D., Plikaytisc, Sacoora, C., Macetea, E., Alonsoa, P., \& Que, B.S. (2015). Under treatment of pneumonia among children under 5 years of age ina malaria-endemic area: population-based surveillance studyconducted in Manhica district- rural, MozambiqueSozinho. International Journal of Infectious Diseases 36(2015) 39-45.

Ahmed, H. M., Mitchell, M., \& Hedt, B. (2010). National implementation of integrated man-agement of childhood illness (IMCI): policy constraints and strategies. Healthpolicy 2010 Jul;96(2):128-33. https:// doi.org/10.1016/j.healthpol.2010.01.013

Baiden, F., Owusu-Agyei, S., \& Bawah, J et al. (2011). An evaluation of the clinical assess-ments of under-five febrile children presenting to primary health facilities inrural Ghana. PloS one 2011;6(12). https://doi. org/10.1371/journal.pone.0028944

Byrne, B. M. (2013). Structural equation modeling with AMOS: basic concepts, applications, and programming. Routledge.

Dagne, H., Andualem, Z., Dagnew, B., \& Taddese, A. A. (2020). Acute respiratory infection and its associated factors among children under-five years attending pediatrics ward at University of Gondar Comprehensive 
Specialized Hospital, Northwest Ethiopia: institution-based cross-sectional study. $B M C$ Pediatric 20, 1-7. https://doi.org/10.1186/ s12887-020-1997-2

Dutta, A., Hajra, G., \& Ramani, S. V. (2016). On incidence of diarrhoea amongchildren in India. Econ Polit Wkly 2016;51(22):121.

Fitriani, H., Setya, A., Nurdiana, P. (2020). Risk factors of maternal nutrition status during pregnancy to stunting in toddlers Aged 12-59 Months. Jurnal Keperawatan Padjajaran, 8(2). https://doi.org/10.24198/ jkp.v8i2.1305

Irimu, G. W., Gathara, D., \& Zurovac, D et al. (2012). Performance of health workers in themanagement of seriously sick children at a Kenyan tertiary hospital: before andafter a training intervention. PloS one 2012;7(7). https://doi.org/10.1371/journal. pone.0039964

Iskandar, A., Tanuwijaya, S., \& Yuniarti, L. (2015). Hubungan jenis kelamin dan usia anak satu tahun sampai lima tahun dengan kejadian infeksi saluran pernafasan akut (ISPA). (The relationship between sex and age of children one year to five years with the incidence of acute respiratory infections (ARI)). Global Medical and Health Communication, 2015, 3(1). https://doi.org/10.29313/gmhc. v3i1.1538

Liu, L., Oza, S., Hogan, D., Perin, J., Rudan, I., \& Lawn, J. E. (2015). Global, regional, and national causes of child mortality in $2000 \mathrm{e} 13$, with projections to inform post-2015 priorities: an updated systematic analysis. Lancet 2015;385(9966):430-440. https://doi. org/10.1016/s0140-6736(14)61698-6

Nair, H., Simões, E. A., Rudan, I., Gessner, B. D., Azziz-Baumgartner, E., Zhang, J. S. F., et al. (2013). Global and regional burden of hospital admissions for severe acute lower respiratory infections in young children in 2010: a systematic analysis. Lancet. 2013;381(9875):1380-90. https:// doi.org/10.1016/s0140-6736(12)61901-1

Pahwa, S., Kumar, G. T., \& Toteja, G. S.
(2010). Performance of a community-based health and nutrition-education intervention in themanagement of diarrhoea in a slum of Delhi, India. J HealthPopul Nutr 2010:553559. https://doi.org/10.3329/jhpn.v28i6.6603

Rahayuwati, L., Nurhidayah, I., Hidayati, N.O., \& Hendrawati, S. (2019). Analysis of factor affecting nutrition status on children. Jurnal Keperawatan Padjajaran, 7(2). https://doi.org/10.24198/jkp.v7i2.1131

Santosham, M., Chandran, A., Fitzwater, S., Fischer-Walker, C., Baqui, A. H., \& Black, R. (2010). Progress and barriers for the control ofdiarrhoeal disease. Lancet 376(9734), 63-67. https://doi.org/10.1016/s01406736(10)60356-X

Savitha, A., \& Gopalakrishnan S. (2018). Determinants of acute respiratory infections among under five children in a rural area of Tamil Nadu, India. J Fam Med Prim Care. 2018;7(6):1268. https://dx.doi. org/10.4103\%2Fjfmpc.jfmpc_131_18

Simon, A. K., Hollander, G. A., \& McMichael, A. (2015). Evolution of the immune system in humans from infancy to old age. Proc. R. Soc. B 2015;282:1-9. https://doi.org/10.1098/ rspb.2014.3085

Troeger, C., Forouzanfar, M., \& Rao, P. C., et al. (2017). Estimates of the global, regional, and national morbidity, mortality, and aetiologies of lower respiratory tract infections in 195 countries: a systematic analysis for the global burden of disease study 2015. Lancet Infect Dis 2017; 17: 1133-61. https://doi.org/10.1016/S14733099(17)30396-1

UNICEF. (2012). Ringkasan kajian kesehatan ibu dan anak. (Summary of maternal and child health studies). Retrieved March 12, 2020, from https://www.unicef.org/.

UNICEF. (2013). Sekitar 35 juta balita masih beresiko jika target angka kematian anak tidak tercapai. (Around 35 million children under five are still at risk if the child mortality target is not achieved). etrieved March 12, 2020, from https://www.unicef.org/ 
Lantin Sulistyorini: Child Health Problems in Agricultural Setting

UNICEF. (2016a). Diarrhoea remains a leading killer of young children, despite the availability of a simple treatment solution. Retrieved March 12, 2020, from http://data. unicef.org/child-health/diarrhoeal-disease. html

UNICEF. (2016b). Committing to child survival: a promise renewed progress report 2014. 2014. Retrieved March 12, 2020, from http://files.unicef.org/publications/files/ APR_2014_web_15Sept14.pdf.
Walker, C. L. F., Rudan, I., \& Liu, L., et al. (2013a). Global burden of childhood pneumonia and diarrhoea. Lancet 2013; 381: 1405-1416. https://doi.org/10.1016/s01406736(13)60222-6

WHO. (2013). Research Priorities for the Environment, Agriculture and Infectious Disease of Poverty. Retrieved < arch 20, 2020, from https://apps.who.int/iris/bitstream/ handle/10665/78129/ 